NBER WORKING PAPER SERIES

\title{
CAREERS AND CANVASES: \\ THE RISE OF THE MARKET FOR MODERN ART \\ IN THE NINETEENTH CENTURY
}

\author{
David W.Galenson \\ Robert Jensen
}

Working Paper 9123

http://www.nber.org/papers/w9123

\author{
NATIONAL BUREAU OF ECONOMIC RESEARCH \\ 1050 Massachusetts Avenue \\ Cambridge, MA 02138 \\ September 2002
}

The views expressed herein are those of the authors and not necessarily those of the National Bureau of Economic Research.

(C) 2002 by David W. Galenson and Robert Jensen. All rights reserved. Short sections of text, not to exceed two paragraphs, may be quoted without explicit permission provided that full credit, including $\odot$ notice, is given to the source. 
Careers and Canvases: The Rise of the Market for Modern

Art in the Nineteenth Century

David W. Galenson and Robert Jensen

NBER Working Paper No. 9123

September 2002

\begin{abstract}
This paper reexamines the process by which a market for a new product - modern painting emerged in Paris in the nineteenth century. Contrary to the accepted account, in which the monopoly of the official Salon was replaced by a competitive market operated by private dealers, we find that the Salon was in fact initially replaced by a series of smaller group exhibitions organized by artists. The Impressionists were thus leaders not only in creating modern art, but also in developing its markets. Our reinterpretation of this episode yields a new understanding of the interactions between artists and markets in the late nineteenth and early twentieth centuries, and for the first time highlights specific ways in which artists' behavior was affected by the structure of art markets during the first half century of the modern era.
\end{abstract}

David W. Galenson

Department of Economics

University of Chicago

1126 E. 59th Street

Chicago, IL 60637

Office: $773-702-8191$

Fax: 773-702-8490

and NBER

Robert Jensen

Department of Art

University of Kentucky

207 Fine Arts Bldg.

Lexington, KY 40502

Office: 859-257-2336

rjens1@uky.edu

and NBER 


\section{Introduction}

\section{I.1. Introduction}

In 1965, Harrison and Cynthia White published a small book, modestly titled Canvases and Careers: Institutional Change in the French Painting World. ${ }^{1}$ The book was quickly accepted by art historians as an innovative and authoritative work, and it has remained popular to the present: a new edition was published in 1993, and Canvases and Careers remains in print today, more than 35 years after its first appearance.

The longevity of Canvases and Careers stems from the significance of its true subject, which is considerably more important than the book's rather restrictive subtitle would suggest. For Canvases and Careers is in fact an account of the emergence of the market for a new product—modern painting —in the $19^{\text {th }}$ century. Unlike art in most earlier eras, modern art has not typically been commissioned by, or produced directly for, specific patrons. And also unlike in most earlier eras, the radical innovations embodied in modern art have made its acceptance problematic. How modern art has been sold, to whom, and under what circumstances, has consequently been of intense interest to many scholars of art as well as to artists.

The emergence and early development of modern art in $19^{\text {th }}$-century France has been the subject of an enormous amount of scholarly inquiry in the decades since the first appearance of Canvases and Careers. Although no single research project has reexamined all the subjects treated by the Whites, a number of studies have produced new information that bears on many of the central issues the Whites considered. We believe that the cumulative effect of this new information has been to overturn many of the Whites' central arguments. We also believe that the new information has made 
possible a new and more accurate account of the emergence of the market for modern art in the $19^{\text {th }}$ century. This paper presents that account.

\section{2. Summary of Canvases and Careers}

Canvases and Careers describes a change in what the authors refer to as the institutional structure of the $19^{\text {th }}$-century French art world, from what they call the Academic system to the dealer-critic system. This section briefly summarizes the authors' account of these two regimes.

The Academic system was controlled by the government's Académie de Peinture et Sculpture (hereafter the Academy). Aspiring artists were educated at the government's Ecole des Beaux-Arts, where they were taught to use traditional methods to emulate the work of their teachers. While at the Ecole students advanced if they passed annual examinations, and participated in a series of contests designed to identify the most talented. After graduation, the goal of young artists was to display their paintings at the Salon, the great annual or biennial exhibition that was the French art world's principal showcase for new work. Admission to the Salon was regulated by a jury. Although its composition varied, a majority of the jury's members were usually associated with the Academy. The Academy consequently used the Salon as a continuing means of control over artists: not only acceptance of their paintings, but preferential placement of their work in the many crowded halls of the Salon, and access to the medals that the jury awarded to recognize distinction, were all central to building the reputations that would create a demand from private clients for the artists' work.

The Whites argue that the Academic system focused not on artists' careers but on the individual canvases shown at the Salon: "By the system's own definition ... each 
canvas led an independent existence as a separate entity with its own reputation and history ... It was the picture, not the artist, around which the official ideology centered ... The Academic system emphasized individual canvases rather than the careers of painters." 2 They contend that this became an increasingly damaging flaw as the number of French artists grew over the course of the century, and the Salon was overwhelmed by massive numbers of unrelated works. Thus what undermined the power of the Salon was not any small group, but rather growing masses of aspiring painters: "Pressure from the greatly expanded number of professional painters on an organizational and economic framework conceived to handle a few hundred men was the driving force toward institutional change."3 After mid-century, the Academic system progressively gave way to a new system.

The new system was initiated by the Impressionists: "The Impressionists seemed to mark a basic new era in art primarily because they ushered in a new structure for the art world. Let us call this new institutional system the dealer-and-critic system." ${ }^{4}$ The new system emerged partly in response to a growing demand for paintings by members of the French middle class. Instead of the large paintings of historical subjects favored by the Academy, which had typically been purchased for public museums and stately mansions, the new buyers wanted smaller paintings of less formal themes to decorate their homes. Private dealers emerged to serve these customers.

The Whites cite a listing that identified no less than 104 art dealers in Paris in $1861 .^{5}$ These dealers created a new system that focused not on individual paintings, but on the careers of artists. Because a dealer would establish a continuing business relationship with an artist, the dealer had an interest in building the artist's reputation, in 
order to create a consistent demand for his work: "A current painting as an isolated item in trade is simply too fugitive to focus a publicity system upon ... [I]t was the career of an artist that had to be the focus of the system." ${ }^{\prime 6}$ Critics also assumed a new importance in this system. Instead of merely judging the works presented to the public at the Salon, their writing could serve as an alternative means of publicizing artists' work. And as the early development of modern art began to shift the interest of artwork from subject matter to technique, critics began to play a more complex role as theorists for new developments. Yet as their primacy in the Whites' name for the new system suggests, dealers were the primary force in creating and developing the new system. The pioneers were the dealers Durand-Ruel, father and son: "The elder Durand, beginning in the 1820 s as a merchant of artists' paper, canvas, and colors ... became the exclusive dealer in works of the then 'modern' school. Constable, Delacroix, and the Barbizon landscapists were his first 'collection."'” Paul Durand-Ruel took over the gallery after his father's death in 1865: "Durand the younger began an aggressive program to create and maintain a bullish market. He bought up large numbers of works by the 'School of 1830.'...His 'campaign in favor of those called Impressionists' began in 1870, when he met Monet and Pissarro in London ... [H]e would make substantial advances to the painters, to be paid off in pictures... The Impressionist's [sic] dealer, in effect, had recreated the role of patron - in the Renaissance sense of the word... [T] he support artists received from him was a close approximation of the patronage relationship of earlier times ... Thus, as speculator and patron, he set a pattern that was soon adopted by other contemporary dealers." ${ }^{p}$ 
With dealers serving as the entrepreneurs, and critics as the publicists and theoreticians for the new art, the dealer-critic system replaced the Academic system: "The Academy and the state were once arbiters of taste, patrons, educators of the young, and publicists. Now these functions were spread out and assumed by different parts of the new system." Competition, in both economic and intellectual markets, was the hallmark of the new system: "dealer-patrons were in competition with one another and each critic was eager to be spokesman for his own artistic movement." ${ }^{10}$ The free market thus became the artist's protector, as “this framework provided more widely and generously for a larger number of artists and particularly for the young untried painter than did the Academic arrangements."11

The dealer-critic system developed over the course of the second half of the century. It benefited the Impressionists only late in their careers, "for they came along before the new system was fully developed and legitimate." 12 But the leaders of the next generation were in a different position: "Gauguin, Signac, and Seurat had been nurtured in the Impressionists' world of café discussions, joint learning and experimentation, group exhibition and dealer competition." 13

The Whites' account of the Academic system giving way to the dealer-critic system has proved appealing and persuasive to a wide range of art scholars. ${ }^{14}$ Yet it is flawed in a number of respects. We will present our own account of the rise of the market for modern art in the $19^{\text {th }}$ century. In so doing we will demonstrate not only how it differs from that of the Whites, but more importantly how this account is central to an understanding of some key aspects of the history of the development of modern art.

\section{The Salon System to 1874}




\section{1. Exhibiting}

The chief institution for exhibiting art within what the Whites called the Academic system was the annual or biennial Salon. An often-difficult alliance between the Academy, successive French governments, and the general population of artists working in Paris controlled the Salon. This partnership underwent many permutations throughout the century.

The Paris Salon, unlike comparable institutions in other Western nations, dominated its nation's art until at least the third quarter of the century. ${ }^{15}$ This occurred not because there was an absence of rival exhibition venues. Rather, both artists and their publics sustained the belief that the Salon was the only truly legitimate arena for exhibiting and evaluating works of art. So deeply did the Parisian art world hold to the certifying function of the Salon that this faith survived the many controversies over the judgment of Salon juries, over who voted for the juries, and over who served on them. Such criticism of the Salon had begun as early as the 1830s and yet no other exhibition was able to acquire a comparable sense of legitimacy within the community of artists until the Impressionist exhibitions of the 1870s and 1880s. As Gustave Courbet observed following the refusal of all the paintings he submitted to the Salon of 1847, "It is bias on the part of the gentlemen of the jury: they refuse all those who do not belong to their school, except for one or two, against whom they can no longer fight, such as MM. Delacroix, Decamps, Diaz, but all those who are not as well known by the public are sent away without a word. That does not bother me in the least, from the point of view of their judgment, but to make a name for oneself one must exhibit, and, unfortunately, that is the only exhibition there is." 
Until 1874, showing at the Salon was a necessary condition for establishing an artist's reputation and career in Paris. Thus no major French artist was able to forego showing at the Salon, at least at the beginning of his or her career, until the last quarter of the century. After 1874 major artists such as Paul Gauguin and Georges Seurat no longer debuted at the Salon, but discovered they could establish their careers outside the review of the Salon's juries. ${ }^{17}$

The Salon grew rapidly over time. Patricia Mainardi has charted the development of the Salon from 1789 to $1889 .{ }^{18}$ In 1806 , under Napoleon, the Salon displayed a total of 705 entries (including paintings, sculptures, and other media). By 1835, the number had grown to 2,336. In 1848, at the century's only jury-free Salon, there were 5,180 exhibits. After the restoration of the jury system this figure shrank to 1,757 in 1852 . Despite efforts by the Salon leadership to keep the number of exhibitors and exhibits down, the number of exhibits quickly rebounded, reaching 4,102 in 1861 and a new record of 5,434 in 1870. Again in 1872 exhibits were restricted to 2,067 only to grow to another record, 7,289 , in $1880 .^{19}$

As the number of exhibits at the Salon grew, almost inevitably the number of works any one artist could show decreased. Limited exhibition opportunities helped to encourage the display of "machines"-special, often quite large works of art, to which an artist might devote unusual effort, with the purpose of attracting attention of the Salon jury, of the press, and ultimately the buying public. But if in this way the Salon appears to have encouraged the exhibition of individual masterworks, a counterbalancing system of prizes and honors ensured that the Salon was able to provide for its favored artists over their entire careers, and not simply year by year as the Whites suggested. As a means of 
rewarding its own, attracting critical attention, and finding patrons for artists, the Salon, together with the Academy and a succession of French governments offered a continuous chain of benefits, to raise its important artists above the yearly or biennial competitions. ${ }^{20}$ This produced a system of escalating awards, towards which artists could strive at regular stages in their careers. Through these awards the Salon juries singled out their favored artists from the crowd and focused public attention upon them. As the sociologist Pierre Bourdieu observed, under this regime painters had "a career, a well-defined succession of honors, from the Ecole des Beaux-Arts to the Institute, by way of the hierarchy of awards given at the Salon exhibitions. ${ }^{21}$ Bourdieu went on to declare that under the Salon system "The artist is a high-level civil servant of art."

Who were these favored artists? Léonce Bénédite, the director of the Luxembourg Museum, surveyed the history of $19^{\text {th }}$-century French painting in 1910, providing a near contemporary canon of important French artists active prior to $1874{ }^{23}$ From the eighty-six artists Bénédite discussed in his survey, we have compiled a short list of artists in Table 1 who had long, successful Salon careers. Table 1 also indicates the kinds of honors they received and the ages at which they received them.

Favored artists were rewarded by the state and the Academy in a number of ways. One was through state commissions. A second was state purchases, typically selected from works exhibited at the Salon. Works of art acquired in this way were generally distributed among France's provincial museums or Paris's museum for living artists, the Luxembourg. ${ }^{24}$ A third means of official recognition lay in Salon prize medals, awarded as first, second, or third-class medals, and accompanied by a cash prize. As illustrated in Table 1 successful artists achieved these medals at intervals throughout their careers. ${ }^{25}$ 
The government further buttressed the Salon medal system by offering another set of medals awarded at the various art exhibitions held in conjunction with the great Expositions Universelle of 1855, 1867, 1876, 1889, and 1900. The French artists who received these special medals and higher cash prizes almost invariably had previously medaled at the Salons. With so many opportunities available, Table 1 indicates that important French Salon artists who debuted after the first quarter of the century often earned at least three medals over their careers and sometimes more.

Successful Salon careers then positioned artists to take advantage of additional components of the award system that the Academy and the state could offer artists. The first was appointments to desirable jobs. These included teaching positions at the Ecole des Beaux-Arts and the coveted position of director of the French Academy in Rome. The second was admission to the Legion of Honor, created by Napoleon. The Legion was divided into four classes of membership, beginning with Chevalier, followed by the Officier rank, then Commandeur, and at the top the Grand Cross. The third type of honor for the most favored artists was election to the French Academy. At the beginning of the century artists could aspire only to six available chairs. These were increased to ten under Napoleon and further increased to fourteen at the beginning of the Restoration. Turnover in membership was very slow. From the beginning of the 1870 s to the end of the century, for example, only four positions came open, thus ensuring the dominance of a handful of men over the official art affairs of France during a period of great innovations in art made by young artists of whom the Academicians did not approve. The fourth and chronologically the last category of honors that the state and Academy could confer on artists was an official retrospective. This was an innovation begun on the 
occasion of the Exposition Universelle in 1855, when four living artists, J.-A.-D. Ingres, Alexandre-Gabriel Decamps, Horace Vernet, and Eugène Delacroix were so honored. Later it became the practice to award retrospectives to recently deceased artists, as was the case for such Salon luminaries as Camille Corot, Paul Delaroche, and Ingres. ${ }^{26}$

The progression up the ladder of the award system was often remarkably predictable. In practice, the awards appear to have been given to favored artists even when their current work did not necessarily merit them. For example, in a diary entry from 1853 Delacroix observed the independence of this system from the specific merits of works exhibited at any year's Salon. "It almost always happens that every painter who seems to me to deserve a third class, a second, or a first class medal has already obtained it... It thus happens that an artist rarely receives a reward for that one among his works which deserves it the most... The man who has done well twice is more meritorious than the man who has done well once."27

The award system offered artists a measure of financial security by building their reputations steadily over the course of their careers. While medals and knighthoods were not in themselves sufficient to guarantee the personal fortunes of artists, these honors significantly publicized their careers in a manner entirely unavailable to artists outside the Salon system. Salon celebrities were given favored access to critical and public attention, and this served to attract dealers to buy their work and to act as agents on their behalf.

This prize system was of course only available to artists who had successfully gained admittance to the Salon. But if until 1874 it was impossible for French artists with serious ambitions to debut anywhere else, merely debuting was also not enough. 
The right to exhibit was rarely secure for younger artists. Thus, the Salon put special pressure on young artists to win their first prize. Medal winners were often given special privileges, such as the right to vote for the Salon jury, or being hors concours - allowed to exhibit without submitting one's work to jury review. Such privileges underwent frequent revision throughout the century, but under every administration, prizewinners held a special status. For example, the importance of winning even a third-class medal was such that in those cases when a medaled artist might subsequently have some or all of his works refused by a Salon jury, it caused a scandal. Among the most celebrated examples of this were the rejections of works by some of the medaled Barbizon landscape painters by the Academy-appointed juries during the later years of LouisPhilippe's government. Although some of these artists were kept out of the Salon until the 1848 revolution once again led to major rule changes regarding jury composition, they were nonetheless able to attract the attention of important collectors and art dealers, such as Paul Durand-Ruel's father, based on reputations already won at the Salon. Durand-Ruel observed in his memoirs that his father discovered real commercial potential in artists once so publicized and honored by the press who were at the same time being suppressed by ideologically motivated juries. ${ }^{28}$

Having won prizes early in one's career, an artist might choose to forego further honors, but for the vast majority of artists the lure of this system remained very strong. Courbet, for example, developed lucrative commercial outlets for his paintings, yet continued to exhibit in the Salon. Similarly, Manet consorted with his Impressionist friends, but refused to abandon the Salon for their renegade exhibitions. Even among the Impressionists the Salon, particularly in times of financial need, remained an attractive 
exhibition alternative. Auguste Renoir, most notably, returned to the Salon during the 1880s when he felt that showing his work in the Impressionist shows had not sufficiently succeeded in establishing his reputation and fortune.

\section{II.2. Promoting}

The Salon's monopoly over the French art market was directly related to its ability to control publicity. Merely exhibiting a work of art in a dealer's shop window or at one of the cultural circles that became popular in the 1860 s could not compete with the Salon as a means of commanding the attention of critics and thereby building one's reputation. Both the daily press and the cultural journals were reluctant to review any alternative exhibition, and would usually do so only under special circumstances. Oneartist shows without state sponsorship suffered consistently from critical neglect. Despite his already considerable notoriety, Manet's 1867 self-arranged retrospective drew virtually no response from critics. ${ }^{29}$ James McNeill Whistler, who with Manet had scandalized the public at the 1863 Salon des refusés, was given a one-man show at Durand-Ruel's gallery in 1873 , yet his exhibition was apparently mentioned only once, in an article devoted to the larger issue of japonisme in contemporary French art. ${ }^{30}$ Prior to the 1870 s only the Salon exhibitions had the capacity to attract consistent, serious, and widespread attention from critics. The Salon's monopoly over career-building exhibitions disappeared after 1874 , but such was its prestige that it continued to receive the most critical attention until the end of the century and beyond.

Each Salon was greeted by lengthy critical reviews in the steadily increasing number of daily newspapers and weekly, bi-weekly, and monthly journals. These reviews were often printed over the course of multiple issues of a periodical. Despite the 
fact that many critics complained that the Salon fostered mediocrity, particularly during the second half of the century, Salon-related publications grew more lavish rather than less so, and new, specialized kinds of Salon-related publications appeared, some clearly aimed at the tourist market. ${ }^{31}$ The presence of art criticism was perhaps not the only sign that an artist had passed from being merely exhibited to having acquired a significant reputation, but it was by far the most visible and important indicator.

What role did the Salon itself play in influencing which artists were noticed by the critics? Unfortunately, there has been an astonishing lack of interest by art historians in the relationships between Salon hangings and prizes and their impact on art criticism, despite the fact that students of $19^{\text {th }}$-century French art have long been accustomed to using Salon criticism as a way of understanding contemporary responses to the style and content of this art. ${ }^{32}$ Yet no scholar has attempted to study systematically the process by which artists were selected by reviewers for comments and the possible connection between the chances of being mentioned in a review and an artwork's position within the exhibition..$^{33}$

Between 1789 and the last Salon of the Napoleonic period, the number of exhibits at the Salon averaged 762 . When the exhibitions were reasonably small and in the palace of the Louvre, how high one's work was placed on the wall might be an artist's chief anxiety when it came to drawing critical attention at the Salon. However, between 1815 and 1847, when the Salons averaged 2,181 exhibits, the exhibitions had grown to three times the size of the early Napoleonic Salons. Already it would be easy for an artist to get lost in the crowd. Consequently, under the July Monarchy it became customary to use the Salon Carré in the Louvre as the featured room to display the most honored 
exhibits and to distinguish them from the rest. ${ }^{34}$ When the Salon was moved first to the Tuileries Palace under the Second Republic, and then to the Palais Royal in the early years of the Second Empire, and finally to the Palais de l'Industrie in 1857, the greatly enhanced capacity of these venues put new pressure on Salon juries, who now had one less reason to exclude artists. From 1857 to 1874, the year of the first Impressionist exhibition, the Salon averaged 3,518 exhibits.

Sifting through this mountain of art, critics were likely attracted to an artist's work by at least three factors. The first was the stature of the artist, which of course depended in large part on the previous prizes and titles he or she held. The Salon catalogues indicated after each exhibitor's name the past medals and state honors they had been awarded.$^{35}$ Second, critical attention would also focus on that year's prizewinners. These were also announced in the preface to the Salon catalogue. The third condition, likely related to the first two, would be a favorable hanging, to which artists attached enormous importance. Frédèric Bazille, for example, wrote dejectedly to his parents in 1869 , "I am as poorly hung as possible." ${ }^{936}$ The next year he told them excitedly "I am delighted with my exhibition. My picture is very well hung. Everybody sees it and talks about it. Often more bad than good is said of it, but at least I'm in the swim and whatever I shall show from now on will be noticed." ${ }^{37}$ Having one's work "skied" - hung in the topmost tiers on a wall of canvases—was nearly as bad as being refused outright by the jury. On at least one occasion, during the Salon of 1846, the Salon jury or a designated committee re-hung the exhibition in mid-season in an effort to provide some increased visibility for artists, such as Courbet, who suffered from being skied. ${ }^{38}$ Even during the period between 1861 and 1872, when apparently the Salons 
were hung alphabetically by artist, where one's work was placed on the wall, as Bazille's letters indicate, still remained the decision of a hanging committee. ${ }^{39}$ In short, from the second decade of the century forward, the Salon juries were charged not only with the task of finding places for so many works of art, but also with that of influencing the public reception of any artist's work. ${ }^{40}$

A successful Salon painting served to promote an artist's reputation and to raise public interest generally in the artist's oeuvre. Since only the most successful artists at the Salon could hope to shift the burden of acting as their own business manager to an art dealer, it was an important right for artists to list their studio addresses in the Salon catalogues. They counted on collectors and dealers attracted by their contributions to the Salon to pay studio visits. ${ }^{41}$ There the patron might see and purchase the artist's other work or perhaps even offer the artist commissions for future works.

\section{II.3. Selling}

Very few dealers handled contemporary art on any significant scale until the end of the century. The Whites' observation that in 1861 there were not fewer than 104 different "marchands de tableaux" in Paris significantly overstates the number of art dealers involved with contemporary painting. A number of the dealers listed were probably not primarily sellers of paintings; the same source the Whites used also lists twelve of these dealers as "marchands de curiosités, objets d'art, medailles, etc.," four as "restaurateurs de tableaux," three under "encadrements d'estampes, tableaux, et pastels," three under "tableaux à musique," and one under "mouleurs-figuristes." remaining galleries either did not sell the work of living artists or did so only on occasion. 
In 1867 Philippe Burty, a well-known art critic, contributed an essay on Paris' art market to an artistic guide to the city ${ }^{43} \mathrm{He}$ introduced his discussion of the market for paintings by observing that the trades in "tableaux anciens" and in "tableaux modernes" were completely separate businesses. He observed that the trade in modern paintings had begun relatively recently, and that shops that specialized in this trade had been founded only after 1848. According to Burty, the one exception was the gallery Adolphe Goupil had founded in the 1820s; the specific painters he mentioned in connection with Goupil's gallery were Vernet, Delaroche, and Gérôme. Burty mentioned by name only one other dealer in modern paintings, Francis Petit, whose gallery he strongly recommended for the range of works available: Burty mentioned specifically Troyon, Dupré, Isabey, Jongkind, Rousseau, Millet, Decamps, Delacroix, Ziem, and Meissonier as artists represented there${ }^{44}$ After praising Petit's gallery, Burty mentioned no other dealer by name, but simply concluded by stating that there were another ten galleries nearby at which collectors could see the work of the best contemporary French artists.

Burty's testimony that there were relatively few galleries devoted to contemporary art in Paris is supported by several other sources, most notably the records of the American art agent, George A. Lucas. According to the editor of Lucas' business diaries, the agent spent on behalf of the New York dealer Samuel Avery "over two and one half million francs... primarily for paintings bought prior to the latter's retirement at the end of $1885 .{ }^{{ }^{45}}$ In the 1860 s alone Lucas expressed interest in or bought the work of just fewer than one hundred different artists from the commercial galleries he visited. As a significant purchaser of contemporary French painting, it is striking that Lucas mentioned just twenty-eight galleries in connection with these artists during this decade. 
Lucas records just eight dealers exhibiting paintings by five or more artists of interest to him, and only four galleries possessed the works of ten or more such artists. Mirroring Burty's remarks, the gallery in which Lucas records seeing or purchasing the work of the largest number of artists - more than 30-was Goupil's, followed in order by Petit's, whom Lucas visited in connection with over 20 different artists, and by Durand-Ruel's, in connection with which Lucas listed 12 artists.

We have no way of knowing whether Lucas's involvement with the galleries named repeatedly in his diaries in relation to contemporary French painting represents a complete survey of all the important galleries which sold this art. During the 1860 s over $90 \%$ of the artists Lucas noted in diaries in relation to a commercial gallery had already won medals at the Salon. One might argue, perhaps, that the works by young, unmedaled, or controversial artists such as Manet and the Impressionists might not have been shown in the galleries Lucas visited, but would have been elsewhere. Yet recent scholarship on the Impressionists' dealers have added few names to the list of dealers that might have escaped Lucas' notice and with whom young artists might have exhibited. For example, Sophie Monneret's dictionary of Impressionism, L'Impressionisme et son époque, mentions in her entry on art dealers only sixteen firms, and of these Lucas recorded visits to all but one gallery active during the 1860 s, a dealer whom we know ran a very small shop, Louis Latouche. ${ }^{46}$ In another recent book that addressed the dealers associated with Impressionism, Anne Distel added seven names to those provided by Monneret. ${ }^{47}$ Of these Distel found five dealers with whom Lucas did not do business; yet these same dealers appear to have conducted their businesses on a small scale; almost nothing is known about them. Four of the five in fact were at various times employees or 
agents of Durand-Ruel's and it is primarily his archives that document the galleries' existence.

Distel and Monneret together list a total of 23 dealers of contemporary painting, a figure that is less than a quarter of the 104 dealers cited in the 1861 business directory. Of these, the larger firms, which were capable of making substantial investments in an artist's work and had the resources to buy and sell paintings at high prices, may be distinguished from the smaller galleries, which acquired paintings piecemeal, generally buying and selling at low prices. Besides Goupil, Petit, Brame, Durand-Ruel, and a few others, the remaining twenty-odd galleries handling contemporary painting during the 1860s probably ran their businesses much in the manner described by Emile Zola in his novel L'Oeuvre, through the practices of the fictional character of Malgras. Zola based Malgras on Pierre-Firmin Martin, more popularly known as Père Martin. ${ }^{48}$ Such dealers, according to Zola, paid young or otherwise unknown artists very small sums for their paintings. Although Martin often went on to sell pictures acquired in this way to important collectors, he did so with relatively little profit to himself, and none to the artists. Dealers such as Martin might keep a young artist from starving, but they could do little to advance an artist's position in the profession. Theirs was a trade in canvases, not careers.

It is the small group of dealers led by Goupil who best fit Albert Boime's description of "entrepreneurial dealers." ${ }^{49}$ Such men took advantage of changing market conditions, by promoting artists who themselves had begun to look beyond the state to the new, middle-class audience for art. To this audience these dealers sold landscapes and genre paintings as well as print reproductions after Salon originals. Their success 
eventually encouraged even many history painters to work on a small scale. Goupil's involvement in the print trade in the 1830s made him aware relatively early of the rising demand for affordable art for the middle class. He was able to give his artists access to this new clientele through his print publishing house and distributed via his many local and international galleries and business partners. Soon sales of photographs and print reproductions became a standard practice among these internationally minded dealers. Durand-Ruel père promoted William Bouguereau's paintings during the 1860s with elaborate photographic reproductions, displayed in "gilded rattan" frames; these photographs were often sold by middlemen and distributed across Europe and America. ${ }^{50}$ Exclusive contracts with important artists also became increasingly standard practice. Bouguereau signed an exclusive contract with Goupil in 1865; for the next twenty years the artist gave the dealer between ten and twelve paintings a year. ${ }^{51}$ Goupil, Durand-Ruel père, and the Petit gallery all established close, long-lasting relationships with a small number of artists, who owed the dealer's patronage to their success at the Salon. Both artist and dealer received a measure of financial security from this contractual arrangement. The dealer had the assurance that the artist, presumably already in demand by collectors, would sell only through his firm, at fixed rates. In return the artist received a regular and sometimes very substantial income.

During the 1860s Petit, Hector Brame, and Durand-Ruel's son Paul began to invest heavily in Ecole de 1830 artists, with the intent to control as much of these once scorned, but now celebrated artists' output as possible so that potential buyers would have to come to the dealer. ${ }^{52}$ Brame, for example, offered an exclusive contract for three years to Jean-Francois Millet in 1860. And in a well-known incident Paul Durand-Ruel 
tried to wrest control from Petit of the work of the landscape painter Théodore Rousseau in 1867 , by entering into partnership with the wealthy Brame to purchase seventy paintings from the artist. $^{53}$ Mass purchases like these tended to favor artists near the end of their careers, rather than offering significant income to an artist over a long period of time.

For the already well-established artist, the large dealer's gallery was the most convenient means to translate one's reputation into sales. But young, unknown artists were never beneficiaries of large-scale dealer purchases. For the entry-level artist, the problem remained constant throughout the century: by what means could such a reputation be established? Prior to 1874 the only answer was the Salon. With the beginning of the Impressionist exhibitions, the answer began to change.

\section{4. Summary: The Salon System}

The Salon was the central institution in the French art world for the first three quarters of the $19^{\text {th }}$ century. In view of this, we refer to this period as that of the Salon System. Through its control not only over who was allowed to show their work at its exhibitions and where their work was hung, but also over a series of prizes and other honors, the Salon's jury could provide enormous advantages to its favored artists throughout their careers. With thousands of artists competing in Paris' increasingly crowded market for fine art, conspicuous hangings at the Salon and a history of official awards were the surest means of gaining a reputation that would allow an artist to attract favorable attention from critics, and consequently to have his work sold to prominent collectors at the largest private galleries. 
Analytically, the distinctive feature of the Salon system can be isolated by comparing the fine art industry to another creative industry, that of literature. Like painters, authors of books produce highly differentiated products. These are published and promoted by commercial companies, publicly evaluated by critics, and purchased by consumers. In $19^{\text {th }}$-century France, not only were there many writers, literary critics, and purchasers of books, but also many different commercial publishers. For fine art there were many painters, critics, and collectors. Until the 1870 s, however, there was effectively only one prestigious publisher for fine art. A painter's work could not be widely reviewed by critics, or considered for purchase by important dealers and collectors, until the painter had proven himself by being admitted to the Salon, and receiving at least some degree of recognition from the jury. The Salon's effective monopoly of the legitimate presentation of new art to the public gave its jury the power to determine whether an aspiring artist could have a successful career as a professional painter. This monopoly was recognized by Bourdieu, who observed, "through the jury (which it appoints) the Academy can forbid [artists] access to the market, since it has the power to decide who is admitted to the Salon, which accredits the painter and assures him a clientele." 54

Even after it had admitted a painter by hanging his work, the Salon could provide varying degrees of support for the artist: the book publisher's advertising campaign was paralleled by the even more tangible forms of support the Salon could give a painter, including favorable hangings, medals and honorary titles. These endorsements would not only influence the amount of attention the painter's work received from critics, dealers, and collectors, but would also have a direct impact on purchases of the artist's work by 
the government, and on appointments of the artist to desirable government positions. The Salon's monopoly of the legitimate public presentation of new art thus gave it almost complete control over who would be allowed to become a painter in $19^{\text {th }}$-century France, and a very high degree of control over the critical and commercial success that those admitted to the profession would enjoy.

\section{The Salons System after 1874}

\section{III.1. Exhibiting}

Throughout its history the centralized monopoly of the Salon system was challenged by alternative art exhibition organizations. ${ }^{55}$ Yet it is a striking feature of the Parisian art world that until the 1870 s no alternative to the Salon was established on a continuing basis. It is equally striking that after 1874 no artist whom we now recognize as an important contributor to $19^{\text {th }}$-century French art built his or her career at the Salon.

Ironically, it was the French government that created the precedents for effective alternatives to the Salon. In 1857 the government handed exclusive control over the Salon jury to the Academy ${ }^{56}$ The Academy's restrictive juries led disenfranchised artists to demand new exhibition opportunities from the government. Napoleon III's fine arts administration initially responded by granting quasi-official status to a new exhibition society, the Société nationale des beaux-arts, operated under the aegis of the artist and dealer, Louis Martinet, which began operations in 1861, allowing one of its ministers to serve in the society's leadership committee.$^{57}$ Provoked by jury abuses, the community of artists continued to pressure the government, until in 1863 the government felt compelled to create the celebrated Salon des refusés. ${ }^{58}$ 
Imperial involvement in both the Société nationale and the refusés exhibitions meant that they were worthy of significant press coverage. At Martinet's, where Manet regularly showed paintings before 1863 , the artist had his pictures reviewed in the prestigious Gazette des beaux-arts. ${ }^{59}$ And the refusés show subsequently made Manet famous. This is probably the first instance in the $19^{\text {th }}$ century where an important French painter built his reputation outside the Salon. Yet even Manet had debuted at the Salon.

While Martinet's exhibitions and the refusés were important precedents for the Salons system that emerged in the 1870 s, they did not themselves represent permanent alternatives to the Salon. The Société nationale was particularly short-lived; the society disbanded in 1864. A clear weakness of the Société nationale was the fact that artists were allowed to exhibit freely both there and at the official Salon. Consequently, the Société nationale's exhibitions appeared to critics at the time not to be an alternative to the Salon, but merely its adjunct. It may even have appeared to be a second-class adjunct, since the Société nationale did not employ a jury, the conventional guarantee for the quality of the work on display. ${ }^{60}$ Manet, the only French painter to benefit substantially from press attention at either of these institutions, remained clearly still anxious to prove himself at the Salon proper. ${ }^{61}$

The scandal of the refusés exhibition made a deeper impression on the artistic community than did the efforts of the Société nationale, precisely because it was widely perceived to represent the opposition of young artists to the entrenched leadership of the Salon. The efforts of the heroes of the refusés were thus regarded as more than merely failed contributions to the Salon. Unfortunately for later disenfranchised artists, the refusés was by definition a heterogeneous collection of professional and amateur work, 
all which had failed jury review. As the critic Castagnary noted in his review of the Salon of 1873, artists who showed at a refusés exhibition ran "the double risk of being passed over in silence or being included in the general condemnation with which all grotesque and ridiculous works necessarily meet." ${ }^{92}$ This is why the refusés could not be a satisfactory long-term alternative to the Salon. ${ }^{63}$ The novelty of the first exhibition, abetted by the popular perception that the jury had indeed been unduly restrictive, drew a level of press attention and public interest to the show that no later refusés exhibition achieved (the practice of holding refusés exhibitions continued intermittently until 1886). ${ }^{64}$ Artists excluded from the Salon continued to call for new refusés shows, but the rationale for such exhibitions was weakened by the reforms of 1863, which stripped the Academy of its control over jury selection. As long as the public perceived the Salon juries to be elected by a cross-section of the Parisian art community, their decisions had the appearance of resulting from an impartial peer review.

After 1863, the Salon, now governed by a combination of state officials and celebrated artists, continued to rule unchallenged until the Impressionist shows began a new era in the exhibition and promotion of art. Unlike their predecessors, the Impressionist exhibitions became a significant alternative to the Salon because it was the artists themselves who initiated them. It was artists, not dealers, who proved to be the true entrepreneurs of an emerging Salons system.

The Impressionists' success was possible because critics were willing to publicize the works they exhibited. The quantity of reviews was impressive in number for all eight Impressionist exhibitions. The first show, in 1874, received fifty-one individual reviews or notices. ${ }^{65}$ Later shows never received less than forty-four separate notices and review 
articles, and the third show, in 1877, received seventy-four. Unlike dealer-sponsored exhibitions, the fact that the Impressionist shows were able to attract considerable attention from the press allowed them to become an effective rival to the Salon as a venue in which artists could present their work and have it taken seriously by the public.

Throughout the $19^{\text {th }}$ century art critics expressed a deep mistrust of art dealers. The common view was that dealers did not contribute productively to contemporary art, but rather had a deleterious effect on artists, encouraging them to cater to public tastes, debasing themselves for monetary gain. The press generally ignored dealer shows for individual artists, unless the artist already possessed a very significant established Salon reputation. Even then press reviews of commercial gallery shows for individual artists tended to be short, in contrast to the attention given to group shows.

Critics apparently believed that the Impressionist shows were untainted by dealer involvement. The Impressionists were careful never to indicate any sponsor other than the artists themselves. Profits from sales were each artist's alone, save for a contribution to underwrite exhibition costs. This evidently influenced the critics even when the Impressionists exhibited in locales obviously belonging to a merchant, as they did when they showed at Nadar's recently vacated photography studio in 1874 and again at a space rented from Durand-Ruel in $1876 .{ }^{66}$ In 1882 not even the Impressionists' harshest critics mentioned Durand-Ruel's role in organizing the exhibition.

What may also have aided the success of the Impressionist exhibitions was the recognition that the exhibitors represented a specific kind of art, which stood in opposition to the values of the Salon leadership. It was likely the memory of the failure of the Société nationale that led the Impressionists to stipulate that member artists would 
not show at the Salon - a condition Manet, for one, was not willing to meet. An important consequence was that their exhibitions could not in any way be perceived as adjuncts to the Salon. This perception that the Impressionists represented a "bande" of artists in opposition to the Salon is reflected in the criticism of Impressionist exhibitions. Reviewers demonstrated a striking ability to distinguish the core Impressionists from the many fellow travelers whom the organizers enlisted to help give credibility to their shows. Even at the first show, as Table 2 demonstrates, most critics were able to distinguish the major Impressionists from the rest. Twenty reviews singled out individual artists and works of art (as opposed to listing merely their names). Of the thirty-one artists who participated only Degas was mentioned in all twenty reviews, followed by Monet with nineteen, Morisot and Sisley with seventeen and Renoir and Pissarro with sixteen reviews. No other artist was mentioned more than eleven times. ${ }^{67}$ Moreover, almost all of these critics perceived the Impressionists to be doing something new. Whether critics held their innovations to be good or bad subsequently proved to be unimportant. What was important was that critics described the Impressionists' work as a unified challenge to the tastes represented by the Salon jury.

A third factor behind the Impressionists' success was the diminished authority of the Academy, which had not only permanently lost control over the Salon's juries in 1863, but had also lost control over the Ecole des Beaux-Arts. ${ }^{68}$ Even as the Academy was pushed into the background, the government, which under Napoleon III had been actively engaged in controlling and promoting the visual arts, became under the Third Republic increasingly willing to grant artists complete control over the Salon and art instruction. Whereas in the past the legitimacy of the Salon jury's decisions had been 
backed by the outside authority of the Academy and/or the state, now its juries were publicly perceived to represent only the interests of the exhibiting artists, not some ideal standard set by the Academy or state policy. In essence, the Impressionists were the first artists to avail themselves of these altered circumstances and to set themselves up as a distinct faction within the Parisian art community. Without organized opposition, the Impressionists could claim that their aesthetic aims were no less authoritative than any other group of artists. The only outside arbiter was the general public, whose tastes the Impressionists openly disdained.

In 1874, the Impressionists had yet to prove not only the value of their art but also the value of the independent group exhibition. We should therefore not minimize the hardships the Impressionists endured for the sake of their art. But neither should we exaggerate the hostility that greeted their innovations. Ever since the earliest histories of Impressionism, the first Impressionist exhibition was routinely portrayed as a critical disaster, an occasion for a hostile crowd to laugh and for critics generally to condemn the artists who dared to show there. ${ }^{69}$ Scholars recognize today that although there was some negative criticism a majority of critics viewed the exhibition favorably. These friendly critics frequently contrasted the Impressionist show with the perceived weaknesses of the Salon. The second Impressionist exhibition, held in 1876, cemented the institutional achievement of the first exhibition. It was even more widely reviewed and serious critics began to formulate the aesthetic ambitions of the movement. The Impressionists' ability to stage six more shows, stretching over another ten years, demonstrated the viability of alternative, artist-run exhibition societies. 
Besides creating a society that could sponsor a series of exhibitions over a number of years, the format used by the Impressionists was more attractive than that of the Salon. Their shows were small. In 1874 their first catalogue listed 165 works by thirty artists. By comparison, at the Salon of 1874 visitors encountered 3,657 paintings, sculptures, drawings, prints, photographs, and architectural models. Moreover, at the Impressionist show in 1874 Degas was able to show ten paintings, Monet twelve pictures, and Pissarro five. At later Impressionist exhibitions the collection of works by each artist grew considerably larger, so that in 1877 , for example, Degas showed twentyfive pictures, Monet twenty-nine, and Pissarro twenty-two. Again, by comparison, at the Salon, depending on that year's regulations, even a celebrated Salon artist might be able to exhibit no more than two works. Less well-known artists were fortunate to exhibit a single work at any of the Salons. The idea of exhibiting large collections by a single artist was not new with the Impressionist exhibitions, yet nothing on this scale occurred at the Salon. Nor had any artist who lacked medals and state honors had such significant collections of their work reviewed by so many critics.

The Impressionists' group exhibitions were so successful that by the early 1880 s they had inspired a number of similar enterprises. As the academic painter Léon Gérôme ironically remarked in his review of the Impressionist exhibition in 1882, "Paris, in sum, is at the moment swarming in small expositions, of small Salons, as one says: exposition of watercolorists, exposition of the rue Volney, exposition of the Mirlitons, exposition of women artists, exposition of Russian painters, expositions of the cercle des arts libéraux, etc., etc." ${ }^{, 70}$ Yet it is equally notable that the Salons Gérôme listed failed to produce major artists. Clearly the Impressionist exhibitions had distinct advantages over these other 
fledgling organizations. By the early 1880s its core artists had become prominent fixtures in the Paris art world. Critics had well-defined expectations regarding the work they would review at their group shows. It is also some measure of the prestige of the Impressionist shows that they were able to confer legitimacy on younger artists who exhibited with them. This was the case for Gauguin, who exhibited with the Impressionists five times beginning in 1879, and for Seurat, whose painting of the Grande Jatte became a subject of great controversy at the last Impressionist exhibition in 1886.

During the 1880 s only one other exhibition society played a role comparable to the Impressionist exhibitions. This was the Group des Artistes Indépendants, at whose first show Seurat exhibited in 1884. Soon renamed the Société des Artistes Indépendants, the new organization differed fundamentally from the Impressionists' exhibitions, since it presented its shows as being open to all artists, without review of a jury. ${ }^{71}$ Its organizers also represented widely divergent aesthetic positions, from Seurat and Paul Signac's Neoimpressionism to Odilon Redon's Symbolism. And the artists who participated in its shows ranged from barely skilled amateurs to some of the most innovative painters of the day. But like the Impressionist exhibitions, the Indépendants' importance had much to do with the prominence of its innovative artists. Seurat, Signac, and Redon were clearly leading painters within the Parisian community interested in advanced art. And as in the case of the Impressionist exhibitions the Indépendants survived because the press was willing to review their shows. ${ }^{72}$

According to the Whites "The Impressionist group shows... soon withered in favor of one-man shows." ${ }^{73}$ The Salon system, however, was not replaced by a gallery 
system centered on the one-man show, but rather by a Salons system. And the new Salons system was not merely a brief interlude between the erstwhile Salon system and an art world dominated by commercial galleries. The commercial gallery show devoted to a single artist - the dominant format of the art market later in the 20th century-was not even an option for young or unrecognized artists until the end of the century. Members of those groups who chose not to exhibit at the official Salons instead made their debuts in group shows such as the Indépendants, and continued to be the case until at least the beginning of the $1920 \mathrm{~s}^{74}$

\section{III.2. Debating}

The Whites contend that the role of critics expanded as the Academic system gave way to a new order. Critics' ability to publicize art grew in importance: "The laudatory review became a substitute for a Salon medal." ${ }^{975}$ Critics replaced the Salon jury as arbiters of taste: "In the Academic system, painters themselves had been propounders and enforcers of formal theory. Now this role passed to the critics as the new system developed." ${ }^{" 76}$ And the critics became ideologues of innovative art: "Exclusion from the Salon not only made a painter a figure of interest to readers; it became, in articles by favorable critics, a positive reason for the artist's greatness." ${ }^{p 7}$

To the extent that critics attempted to publicize artistic innovators in order to increase sales of their work, they must be judged largely a failure. Whether we consider the art of the Impressionists or that of the leaders of the next generation, advanced art simply didn't sell well in $19^{\text {th }}$-century Paris. The fortunes of Monet and his friends in the 1870s and 1880s, and that of Gauguin and Cézanne in the 1890s, lagged far behind the considerable successes of the leading artists still showing at the Salon. 
Some critics did play an important role in the Salons system, but their primary impact was in the intellectual market for artistic ideas rather than in the economic market for paintings. Under the Salon system, most critics simply reacted to the judgments of the Salon juries. Whether they agreed or disagreed with the jury, the Salon furnished their most important subject matter. With the declining prestige of these juries under the Salons system, some critics perceived new opportunities to exert an influence over contemporary art.

The most notable example of prescriptive art criticism must be that of Charles Baudelaire. In 1863 his essay "The Painter of Modern Life" not only instructed artists as to what subjects they should paint, but gave strong hints about the new methods they should use in the process. Baudelaire's challenge appears to have had a powerful impact on the young artists of his day, and some historians believe that it continued to influence the aesthetic agenda for advanced French art even into the early twentieth century. Although no other critic had a comparable influence on artists' practices, a few others tried, and their efforts were noted by artists. Thus for example when in 1890 Albert Aurier published an article praising van Gogh for his unique innovations in Symbolism, the artist wrote to Aurier in embarrassment, pointing to the contributions of other painters. Yet van Gogh confided to his brother of Aurier's article that "I do not paint like that, but I do see in it how I ought to paint." He recognized Aurier's real intention: "I think the writer really wrote it more to guide, not only me, but the other impressionists as well." 78

Although few critics directly influenced artists' methods, a number made a contribution to advanced art by encouraging young painters, and supporting them within 
Paris' contentious world of advanced art. A number of accomplished men of letters took up the cause of Manet and the Impressionists, as at various times during the 1860s, 1870s, and 1880s Emile Zola, Edmond Duranty, Théodore Duret, and Stéphane Mallarmé declared them to be the most important painters working in France. ${ }^{79}$ Félix Fénéon did the same for Seurat and the Neoimpressionists in the 1880s, and Aurier similarly championed van Gogh, Gauguin, and other Symbolists in the 1890s. Although these artists set their own artistic courses, they clearly appreciated the support of such intelligent and distinguished critics. And some of the artists regarded the critics' work as serious contributions to artistic debates. So for example in 1888 Signac was angered by the claim of critic Arsène Alexander that Seurat saw his "paternity of the theory" of Neoimpressionism questioned by "unscrupulous comrades." ${ }^{\text {"80 }}$ Signac demanded an explanation from his friend Seurat, which the latter provided, denying responsibility for the insult. Yet in his response Seurat provided additional evidence of the significance of critical writing, noting, "I still consider Fénéon's pamphlet [of 1886] as the exposition of my ideas on painting." ${ }^{\prime 1}$ Since none of the painters in Paris' advanced art world were enjoying great financial success in 1888 , the exchange between Signac and Seurat suggests that their interest in critics' writings stemmed from their concern that the public have an accurate perception of their intellectual positions rather than from their economic status. That artists took critical judgments seriously is further demonstrated by the fact that they not only welcomed public praise, they were genuinely hurt when friendly critics abandoned them. The most dramatic example of this occurred when Zola's L'Oeuvre portrayed thinly disguised versions of the Impressionists as artistic failures. Publication 
of the novel not only caused Monet to write an anguished protest to Zola, it resulted in a permanent rift between the novelist and his boyhood friend Cézanne. ${ }^{82}$

In tracing the close relationships between advanced artists and critics throughout the late $19^{\text {th }}$ century, it is important to recognize that the involvement of critics in artistic debates consistently predated dealer involvement in promoting the art under review. Unlike the journalists who wrote for newspapers or other periodicals, or the critics who served dealers, the critics closest to the innovative art of the day were men of letters. They wrote art criticism only on occasion, and often published even their most important essays in obscure or foreign journals or newspapers. The criticism of these men of letters differed considerably in quality, and usually in length, from that of the professional art critics; the latter's work was more widely available to the public at large, but also more ephemeral. The most significant essays of the men of letters reached only limited audiences. Thus while the writings of Mallarmé and Duranty subsequently came to shape the modern reading of Impressionism, and Fénéon that of Neoimpressionism, at the time they were first published they effectively promoted their artists only within Paris's elite cultural circles of those already interested in innovative art. But in applying their considerable talents to articulate and praise the achievements of these early schools of modern art, these and a few other critics gave moral support to these new movements that helped to strengthen the resolve of the handful of innovative artists who led them.

\section{III.3. Selling}

The Impressionist exhibitions broke the Salon monopoly over the ability to present artists' works to the public in what would be generally considered a legitimate setting. In the process they established the reputations of the core participants within the 
Parisian community of advanced art. Only very slowly, however, did the Impressionists find collectors interested in their work. Even after the cessation of the Impressionist exhibitions Pissarro and Sisley still struggled to find buyers for their work. In short, the emerging Salons system inaugurated by the Impressionist shows was a far less economically secure environment for artists whose reputations depended on them than the state-financed Salon had been for artists favored by the juries.

Art dealers proved inadequate substitutes for state patronage. The Whites argued that under the "dealer-critic system" there arose "a few competing nuclei" of dealers "stable enough to serve as effective substitutes for government patronage." ${ }^{\$ 3}$ In reality the competition to which they refer came so late in the century, involved so few dealers, and worked on behalf of so few artists as to be insignificant as a "system" for supporting artists' careers.

As the Whites themselves recognized, there were only a few dealers who were interested in buying advanced painting. The number of important dealers in contemporary art had remained almost unchanged from the previous generation. Paul Durand-Ruel and Georges Petit replaced their fathers in their respective firms. Goupil's gallery was taken over in 1875 by the partnership of Boussod \& Valadon, which continued the firm's practice of promoting famous Salon artists. These three galleries continued to dominate the trade in contemporary painting in Paris as they had during the Second Empire. There were new galleries in Paris in the 1880s, both large and small, but none played a significant role in furthering the careers of those artists whom we now recognize as the most important working in France at that time. The smaller dealers, such as Père Martin and Père Tanguy, bought work a painting at a time, and were unable 
to promote the artists they purchased except through word of mouth. Those fellow artists and collectors interested in advanced painting found the shops of these small dealers, but these galleries played no role in shaping patronage for younger artists.

Of all the major dealers active in the last quarter of the century, only Paul Durand-Ruel bought advanced art in quantity. Durand-Ruel is also the paragon of the Whites' dealer-system, an example of a dealer acting as a "Renaissance-style patron," capable of supporting an artist over an entire career. ${ }^{84}$ Yet it is clear that Durand-Ruel bought from the Impressionists primarily only during two brief and widely separated periods. Table 3 lists what Durand-Ruel paid annually to Monet and Pissarro for their paintings between 1871 and 1885. The dealer first met the two artists in London in 1871. The following year Durand-Ruel purchased a large number of paintings from them both, as well as making a one-time purchase of twenty-three paintings from Manet. ${ }^{85}$ In 1873 he bought a still larger number of pictures from Monet while giving Pissarro slightly less than the year before (generally Durand-Ruel paid Pissarro less per canvas than he did Monet). Nonetheless, Durand-Ruel's aggressive acquisitions ceased after 1873 and did not resume until the beginning of the $1880 \mathrm{~s} .{ }^{86}$ During the most important period of the Impressionists' struggle to leave the Salon behind, they could not look to Durand-Ruel for significant financial assistance.

After the Impressionists had won substantial reputations at their independent exhibitions, Durand-Ruel again began to buy their work in quantity. Between 1882 and 1884 he purchased large numbers of paintings from Monet and Pissarro, as well as from Renoir and Sisley, and probably Degas. ${ }^{87}$ The secondary literature offers only a fragmentary accounting of Durand-Ruel's direct purchases from the Impressionists in the 
second half of the $1880 \mathrm{~s}$, yet it appears that the dealer's payments to the artists annually declined from 1884 to the end of the decade. ${ }^{88}$ In Pissarro's case the decline was precipitous. ${ }^{89}$ Between 1887 and 1890 , the dealer bought paintings from the artist at the rate of less than a thousand francs per year. Only after 1890 did the Galerie Durand-Ruel begin again to purchase from the Impressionists in quantity.

Durand-Ruel consequently did not provide effective, continuous support for his artists, not even at the level of Goupil's activities on behalf of painters such as Gérôme a generation before. His effectiveness as a promoter of the Impressionists was similarly limited. Anne Distel has identified just over two-dozen collectors who bought paintings by the Impressionists in Paris during the 1870 s and early 1880 s. $^{90}$ Of these only twothe singer Jean-Baptiste Faure and the merchant Ernest Hoschedé—appear to have become acquainted with the work of the Impressionists through Durand-Ruel. Most of the others bought directly from the artists' studios, having met the painters through other artists or writers. So for example the engineer and artist Henri Rouart, a schoolmate of Degas, not only became an important collector of Impressionist paintings, but also appears to have influenced several others, including his younger brother Alexis, his partner Java Mignon, and the manufacturers Gustave Muhlbacher, Charles Jeantaud, and Edouard Laine, to buy paintings from the Impressionists. The publisher Georges Charpentier met the Impressionists through Zola and other authors whose work he published, and not only collected their work, but allowed them to exhibit their paintings in the office of his magazine, La Vie Moderne, on the Boulevard des Italiens. Renoir's portrait of Madame Charpentier also appears to have convinced the banker Paul Berard to commission the first of what became a series of portraits of his own family from the 
artist, as the two became close friends. Finally, one of the most important collectors and financial supporters of the Impressionists was the painter Gustave Caillebotte, whose introduction to the group also had nothing to do with Durand-Ruel. Thus although there were relatively few collectors of the Impressionists' work in Paris during the '70s and early '80s, most of those collectors who did buy in this early period appear to have learned of the artists through other contacts in the art world rather than through the efforts of Durand-Ruel.

Writers who have praised Durand-Ruel's advocacy of the Impressionist cause have tended to single out his role in opening the American market for their art as his crowning achievement. ${ }^{91}$ It is probably true that the American venture narrowly rescued Durand-Ruel's firm from bankruptcy, but this fact should not be confused either with the escalating prices for Impressionist painting in the later ' 80 s and ' 90 s or with the discovery of important American collectors of Impressionism.

We do not know precisely how many American collectors made their first purchases of Impressionist pictures from Durand-Ruel's American exhibitions and New York gallery, but we do know that the most important collectors came to this art through Mary Cassatt. ${ }^{92}$ Prior to Durand Ruel's New York venture, the artist had already found a small number of American collectors for the Impressionists. She was herself a modest collector of her colleagues' work and she convinced some of her family and close friends to buy their paintings, including her brother Alexander, his business associate Frank Thomson, Louisine Elder, who later married Henry Havemeyer, and Anne Riddle Scott. Beginning in 1889, under Cassatt's tutelage, the Havemeyers and the Potter Palmers began to build what would become the two largest American collections of 
Impressionism. Eventually the Palmers and the Havemeyers developed close relationships with Durand-Ruel and his sons, but their initial acquaintance with the Impressionists' work was due to Cassatt. Durand-Ruel, then, stimulated but did not create the American market for Impressionism and it is quite possible that the Americans would have begun buying the Impressionists without Durand-Ruel's intervention.

Returning to the Whites' assertion that in the 1880s artists were now able to take advantage of a "competing nuclei" of dealers, the record actually shows that during the '80s only Monet was in a position to play one dealer against another, and only with limited success. In the early ' 80 s, while Durand-Ruel was acquiring large numbers of Monet's paintings from the artist, Georges Petit, the dealer's principal rival, had bought at most only a handful of Monet's pictures. Even in 1885, after having shown in Petit's gallery for two years, Monet was still forced to depend on Durand-Ruel for purchases, because, according to Daniel Wildenstein, "no other prospect presented itself. Certainly Georges Petit, who had bought a picture during the International Exhibition, was taking his time paying for it. Durand-Ruel thus remained Monet's confidant for better and for worse..." ${ }^{93}$ Théo van Gogh, the artist's brother and the business manager for a branch of Boussod and Valadon, acquired fourteen paintings from Monet in 1887, making him the first dealer besides Durand-Ruel to make such significant acquisitions directly from an Impressionist painter. ${ }^{94}$ But rather than competing with Durand-Ruel, van Gogh appears to have largely replaced the older dealer as the principal buyer of Monet's canvases. And if Monet fared comparatively better with dealers than had most of his friends in the second half of the $1880 \mathrm{~s}$, it was because he had become significantly more popular with collectors than had his colleagues. 
The idea of fueling consumer demand undoubtedly lay behind Monet's celebrated involvement with Georges Petit during the 1880s. What Monet wanted from Petit was the opportunity to exhibit in the annual and highly fashionable exhibitions of the Petitsponsored Société internationale des peintres français et étrangers, held in Petit's famously luxurious gallery. This society, which began in 1883, was modeled on the financially and socially successful exhibitions of London's Grosvenor Gallery. It specialized in showing artists with already significant reputations, mixing French with foreign artists, and targeted foreign tourists, drawn to Paris each spring, and high society. ${ }^{95}$ Petit's willingness first to include Monet, then the other Impressionist in the exhibitions of the Société internationale reflected their hard-won reputations at the Impressionist exhibitions, but represent little financial risk to the dealer.

Monet jeopardized his relationship with Durand-Ruel in the hopes of attracting new patrons by showing at the Société internationale. The other Impressionists had even less hope of playing dealer against dealer when they showed at the Société internationale; they were simply desperate. Pissarro, in fact, was still complaining in 1891 about the lack of competition between dealers: “At Boussod \& Valadon's they soft-soap me and talk against Durand. If I go to Durand's they become furious, and if I go to Boussod's, Durand is no more furious; in short: neither will buy my work. If anyone else were available, I would unhesitatingly turn to him, but there is nobody." 96

The leading galleries, moreover, were wholly indifferent to the new generation of artists, painters such as Gauguin, Signac, and Seurat, whom the Whites asserted also took advantage of the competition among dealers. ${ }^{97}$ Théo van Gogh was the only dealer sympathetic with this new generation of advanced painters. For example, he gave 
Gauguin a small show in January of 1888, along with Pissarro and Guillaumin.

Significantly, only Fénéon apparently reviewed the exhibition. Van Gogh again gave Gauguin a one-man show in November 1888, which seems not to have been reviewed at all. ${ }^{98}$ Gauguin would show publicly only twice more before 1892 . In neither case was it with a dealer. The first occasion was the artist-arranged exhibition at the Café Volpini in the summer of 1889. And in 1891, Gauguin resorted to exhibiting at the Salon du Champ de Mars, one of the now two officially sponsored Salons in Paris. In 1892 he held an auction to raise money for his Tahitian voyage and subsequently left France. As for Seurat and Signac, if it had not been for the exhibitions of the Independents, their paintings would not have been seen in Paris at any time during the 1880 s.

In the 1890 s new dealers, especially Ambroise Vollard, began to buy and to show the Postimpressionist generation, but none of these artists were given financial security by Vollard or any other dealer prior to 1900 . Young artists continued to debut in group shows and to hope the reputations won there, through favorable criticism and subsequent collector interest, would rouse the support of a dealer, but never in the $19^{\text {th }}$ century would dealers introduce and promote the reputation of unknown artists.

\section{4. Summary}

The official Salon had been the key institution in the French art world until 1874. Although it would not be recognized until later, the first Impressionist group exhibition in that year began a new era, in which the reputations of advanced artists would no longer be created in the Salon, but instead in alternative group exhibitions and Salons. The most important of these would be the eight Impressionist exhibitions and the Salon des 
Indépendants. In recognition of the continuing importance of group exhibitions, we refer to the period from 1874 to the end of the century as that of the Salons system.

Analytically, the critical change that the Impressionists initiated in 1874 was the breakdown of the Salon's monopoly of the ability to present fine art in a public setting that critics and the public would accept as legitimate. Monet and his friends were the first $19^{\text {th }}$-century painters to become leaders in Paris' art world without having received medals and other honors from the official Salon. Increasingly, critics showed themselves willing to devote attention to exhibitions sponsored by groups of artists, even if they lacked the official sanction of the state or any of its institutions. The reputations of the Impressionists quickly became established in the advanced art world, and the demand for their work gradually began to grow among collectors with ties to that community.

The role of dealers changed little in the decades after 1874. As had been true earlier in the century, dealers remained unable successfully to create reputations and markets for young unknown painters. As before, dealers primarily restricted their activity to exhibiting and selling the work of artists whose reputations had already been established, and whose work was already in demand by collectors. The Whites contend that in this period "the dealer... was able to offer [artists] a ready-made clientele and to personally influence its taste," and that consequently "a contract with the dealer, or at least a fairly steady system for loans and advances, guaranteed the painter a minimum income." 99 In their view Durand-Ruel pioneered this arrangement: the artist "wanted above all a predictable income ... This was the carrot Durand-Ruel wielded with such success that other dealers followed." ${ }^{100}$ Yet in fact no dealer offered advanced artists a ready-made clientele, and no dealer, including Durand-Ruel, provided a guaranteed 
minimum income to any artist whose work was not already in demand from collectors. Durand-Ruel deserves credit for being the first dealer to recognize the importance of the Impressionists, but he did not become a consistent source of financial support for these artists, nor was he the first dealer to make large-scale investments in the work of individual artists. Contrary to the Whites' portrayal, dealers were not leaders in the development of modern art and its markets in the late $19^{\text {th }}$ century, but remained followers. They played their role only after talented painters had created the new art, and sophisticated critics had analyzed it.

In the last quarter of the century a number of ambitious young artists decided not to seek the honors offered by the official Salon, and the financial rewards that typically accompanied them. Some of these artists regarded their defection from the Salon as a temporary expedient, while others came to see it as a permanent strategy, but whatever their intention this decision invariably resulted in an extended period of economic uncertainty. For outside the Salon system no young advanced painter found sufficient patronage, from either dealers or collectors, to earn a stable income sufficient to allow him to develop his art without severe economic hardships. Neither Durand-Ruel nor any other dealer supported a young innovative artist in the absence of a steady demand by collectors for his work, and no dealer by himself could readily find the collectors who could create this demand. The market for advanced art remained too limited to provide a secure livelihood for any but the most established painters: collectors' understanding of the principle that important art would be innovative was not yet sufficiently widespread to create large-scale demand for the work of young artists. The art of the Impressionists began to sell in the late $19^{\text {th }}$ century, but neither they nor any advanced artist of the next 
generation would gain consistent economic success until he had established his importance in the art world's intellectual market over a period of at least a decade, and often considerably more.

\section{Conclusion}

In view of the substantial number of issues treated here, it is perhaps worth summarizing what we consider our principal specific disagreements with Canvases and Careers. In each case, our response to the Whites has been explained above in the text; we repeat them here for the sake of clarity.

1) "The Academic system emphasized individual canvases rather than the careers of painters." $" 101$ The Salon system in fact supported the entire careers of favored artists.

2) "Pressure from the greatly expanded number of professional painters on an organizational and economic framework conceived to handle a few hundred men was the driving force toward institutional change." 102 The Salon system was not brought down by masses of artists, but by a few key individuals who demonstrated that its monopoly as a legitimate showcase for fine art could be challenged successfully. ${ }^{103}$

3) The second half of the $19^{\text {th }}$ century witnessed the rise of a new system: "Dealers and critics ... recognized the dominant tastes of the art market ... Essential to success for the new system were the tactile skills of dealers and critics in exploiting situational advantages."104 The true entrepreneurs of the Salons system were in fact artists. Commercial success came only after these artists had achieved success in the intellectual world of advanced art. Dealers in the late $19^{\text {th }}$ 
century overwhelmingly continued to do what they had done earlier: exhibit and sell the work of artists whose reputations had already been established at group shows.

4) "Through dealer-patrons the free market was coagulated into a few competing nuclei, stable enough to serve as effective substitutes for government patronage." ${ }^{105}$ During the $19^{\text {th }}$ century only a few successful artists benefited from competition among dealers-many fewer than had enjoyed government patronage under the Salon system.

5) "[The dealer-critic system] provided more widely and generously for a larger number of artists and particularly for the young untried painter than did the Academic arrangements ... Gauguin, Signac, and Seurat had been nurtured in the Impressionists' world of café discussions, joint learning and experimentation, group exhibition and dealer competition."106 Dealers did not support young untried painters during the late $19^{\text {th }}$ century; they rarely even showed their work. Gauguin, Signac, and Seurat never received a large or steady income from dealers in the $19^{\text {th }}$ century. For most artists, the Salons system was a series of episodes, based on periodic group exhibitions, and consequently focused on individual canvases rather than careers.

Why does our revision of Canvases and Careers matter? One motive is simply to correct our understanding of the historical record. We believe that the Whites' analysis credits the wrong people for changing the art world in the $19^{\text {th }}$ century, and overstates the improvement in the position of advanced artists attributed to that change. Interestingly, we believe that Meyer Schapiro understood these points correctly: 
In the nineteenth century the Salon as the chief place of contact of artists with the public became larger and larger: Prizewinners were guaranteed government support, commissions, purchases, portraits, orders, and appointments in government schools. Juries had a power of life and death over many artists who could show only in Salons. Few dealers handled contemporary paintings. The fight against the jury system, however, did not solve the problem. New Salons, independent places of exhibition, were set up by artists, but the economic situation remained about the same. ${ }^{107}$

We also believe that our revision of the Whites helps to produce a better understanding of the interactions between artists and markets in the late $19^{\text {th }}$ century, and in so doing leads to improved understandings of artists' behavior in this era. One important example involves the issue of why it was the Impressionists who initiated the challenge to the Salon. This may have stemmed from their realization that, as experimental painters, their procedures were not well suited to fighting for acceptance on the Salon's terms. Specifically, their experimental methods made it difficult for them to produce the grandes machines that could gain attention at the Salon. ${ }^{108}$ In contrast, their new group shows allowed them to create a new setting that maintained elements of the Salon, to reassure the critics and public of the integrity of the institution, but that was better adapted to their experimental art in allowing each painter to exhibit a larger number of works.

The persistence of the importance of large group shows through the end of the $19^{\text {th }}$ century and beyond also helps to explain the persisting practice of many advanced artists in preparing grandes machines even after the decline of the official Salon. Our revision of the Whites thus leads to a clearer understanding of the behavior not only of artists like Seurat and Gauguin, but also that of Matisse and Picasso. ${ }^{109}$ 


\section{Notes}

We thank participants in a seminar at the Ecole des Hautes Etudes en Sciences Sociales for their comments on this paper. David Galenson thanks the National Science Foundation for financial support.

\footnotetext{
${ }^{1}$ Harrison C. White and Cynthia A. White, Canvases and Careers: Institutional Change in the French Painting World (Chicago and London: University of Chicago Press, 1993). 2Ibid, pp. 88, 155.

3Ibid., p. 155.

${ }^{4}$ Ibid., p. 2.

5Ibid., p. 97.

6Ibid., p. 98.

${ }^{7}$ Ibid., p. 124.

8Ibid., pp. 124-29.

${ }^{9}$ Ibid., p. 151.

10Ibid., p. 151

${ }^{11}$ Ibid., p. 151.

12Ibid., p. 151.

13Ibid., p. 151.

${ }^{14}$ E.g. see T. J. Clark, The Painting of Modern Life (Princeton: Princeton University

Press, 1984), p. 260; John House, Monet (New Haven: Yale University Press, 1986), p. 234, n. 25; Patricia Mainardi, "Nineteenth-Century French Art Institutions," Art Journal, Vol. 48, No. 1 (Spring 1989), p. 7; Nicholas Green, "Circuits of Production, Circuits of Consumption: The Case of Mid-Nineteenth-Century French Art Dealing," ibid., pp. 29, 33, n.6; Dario Gamboni, "Critics on Criticism: A Critical Approach," in Malcolm Gee, ed., Art Criticism Since 1900 (Manchester: Manchester University Press, 1993), p. 40; Michael C. Fitzgerald, Making Modernism (Berkeley: University of California Press, 1995), p. 7; Martha Ward, Pissarro, Neo-Impressionism, and the Spaces of the AvantGarde (Chicago: University of Chicago Press, 1996), p. 4; David Cottington, Cubism in the Shadow of War (New Haven: Yale University Press 1998), p. 37; John O'Brian, Ruthless Hedonism (Chicago: University of Chicago Press 1999), pp. 12, 41-42, 105; James Rubin, Impressionism (London: Phaidon, 1999), pp. 331, 440; and Philip Nord, Impressionists and Politics (London: Routledge, 2000), pp. 71, 118.

${ }^{15}$ For a further discussion of the centralization characteristic of the French art institutions and its ability to control the display and publishing of works of art, see R. Jensen, Marketing Modernism in Fin-de-Siècle Europe (Princeton: Princeton University Press, 1994), pp. 22ff.

${ }^{16}$ See Letters of Gustave Courbet, ed. Petra ten-Doesschate Chu (Chicago: University of Chicago Press, 1992), p. 70.

${ }^{17}$ Seurat did have a drawing accepted by the jury at the Salon of 1883 , but this hardly constitutes a debut. A year later, Une Baignade, along with a number of other paintings, were again rejected by the jury. Seurat turned to the first exhibition of the "Groupe des Artistes Indépendants" to show his work and never again placed his paintings before the Salon juries.
} 
18P. Mainardi, The End of the Salon (Cambridge: Cambridge University Press, 1993), pp. 18-19. ${ }^{19}$ Ibid., p. 47.

${ }^{20}$ The changing rules of the Salon concerning admission, frequency of occurrence, selection of jury, the number and nature of prizes, and other such factors which the State might be tempted to alter for various reasons of its own have been described by Clara Stranahan in A History of French Painting (New York: Putnam and Sons, 1893). ${ }^{21}$ Pierre Bourdieu, "Manet and the Institutionalization of Anomie," in The Field of Cultural Production (New York: Columbia University Press, 1993), p. 242.

22Ibid., p. 243.

${ }^{23} \mathrm{~L}$. Bénédite, Great Painters of the XIXth Century and Their Paintings (London: Sir Isaac Pitman and Sons, 1910).

${ }^{24}$ Because the pattern of state purchases at the Salon has never been systematically studied, we don't know whether an artist might expect the state to acquire works on a regular basis, or, at steadily higher prices.

${ }^{25}$ Only during the Third Republic was it stipulated that artists could only be allowed to qualify for a higher medal after earning the medal beneath it.

${ }^{26}$ See Jensen, Marketing Modernism, pp. 197-25.

${ }^{27}$ The Journal of Eugene Delacroix, trans. Walter Pach (New York: Viking Press, 1972), p. 322.

${ }^{28}$ P. Durand-Ruel, "Mémoires," in Les Archives de l'Impressionnisme, Lionello Venturi, ed., vol. 2 (Paris and New York: Durand-Ruel, 1939), p. 163.

${ }^{29}$ In Manet and His Critics (New York: W.W. Norton, 1969), p. 107, George Heard Hamilton noted that none of the major periodicals reviewed Manet's exhibition except the Journal amusant, which devoted three pages of caricatures to the show. Hamilton concluded that this was because "the public was convinced that the paintings were worthless." Yet Hamilton's observation does not agree with the fact that Manet's pictures at subsequent Salons were often extensively discussed.

${ }^{30}$ Ernest Chesneau, "Le Japonisme dans les arts," Musée Universel, vol. 2 (1873), pp. 214-17. According to Geneviève Lacambre, "Whistler and France," in James McNeill Whistler, ed. Richard Dorment and Margaret F. MacDonald (London: Tate Gallery, 1994), pp. 39-48, esp. p. 45, Whistler regarded the Durand-Ruel show such a failure that he chose not to exhibit in Paris again for another nine years. Notably, when he showed again, it was at the Salon of 1882.

${ }^{31}$ One such publication was produced by the Goupil publishing house annually during the late 1880s and early 1890s. These volumes were lavishly illustrated and written by famous French critics and were reprinted in English translations. For example, see Georges Lafenestre, The Salon of 1889, trans. Henry Bacon. (Paris: Goupil \& Co.; Boston, Estes \& Lauriat, c1889).

${ }^{32}$ Reading Salon reviews as a means of evaluating what the art meant to its own time is at least a century old. But a new level of sophistication was brought to the technique with T. J. Clark's The Absolute Bourgeois (London: Oxford University Press, 1971) and The Image of the People (London: Oxford University Press, 1973).

${ }^{33}$ For example, no one has compared the reviews of any given Salon. How consistent were mentions of specific artists, or paintings, across reviews? Knowing this would help 
to understand the influence of Salon juries, prizes, and hangings over the critical reception of the art in question.

${ }^{34}$ Courbet, for example, observed in a letter to Charles Blanc in March 1850 that his first picture at the Salon had been hung in the Salon Carré, which he described as "the place of honor" and which "thus afforded the opportunity of there announcing my profession..." Cited in Stranahan, p. 196. The Salon Carré had been in the earliest years of the Salon the only room in the Louvre devoted to the exhibition. As the Salon grew and spread to adjoining rooms in the palace it remained the room one entered first. See Maxine du Camp's description of attending the Salon during the July Monarchy, cited in Jacques Lethève, Daily Life of French Artists, trans. Hilary E. Paddon (New York: Praeger, 1972), p. 118.

${ }^{35}$ We can take the Salon of 1861 's catalogue as typical for the century. Under the title Explication des ouvrages de peinture, sculpture, gravure, lithographie et architecture des artistes vivants, exposés au Palais de Champs-Élysées (Paris: Charles de Mourgues Freres, 1861), the catalogue prints the winners and runners-up for the three classes of medals. A typical entry, for William Bouguereau, notes that the artist had won the Prix de Rome in 1850, a second-class medal in 1855, and a first class medal in 1857. Bouguereau exhibited five paintings, the most permitted to exhibitors at that Salon. ${ }^{36}$ Cited in Rewald, The History of Impressionism, p. 217.

${ }^{37}$ Ibid, p. 242.

${ }^{38}$ Letters of Gustave Courbet, p. 63. Art historians have not studied the history of Salon hanging practices, so it is difficult to say whether such re-hangings as occurred in 1846 could provoke a fresh round of criticism and therefore be of real benefit to an artist. ${ }^{39} \mathrm{On}$ the innovation of hanging in alphabetical order in 1861, see Adolphe Tabarant, $L a$ Vie artistique au temps de Baudelaire (Paris: Mercure de France, 1963), p. 277. See also Mainardi, The End of the Salon, p. 74.

${ }^{40}$ In 1873, the state published a new regulation for the Salon to the effect that "Quand le travail du placement sera terminé, le jury tout entier sera invité à donner son avis sur les dispositions générales ou particulières, mais pendant les travaux du placement, les portes seront fermées à tout le monde sans exemption." The critic who reported this news concluded gladly that "Enfin! ou ne verra plus MM. les membres du jury promener leurs oeuvres de panneau en panneau et de salle en salle, jusqu'à ce qu'il reste à peine le temps materiel d'accrocher le communales admis." See Ernest Fillonneau, "Exposition National," Moniteur des Arts, v. 16 (January 24, 1873), [p. 2].

${ }^{41}$ The diaries of the American art agent George Lucas indicate how important studio visits could be for artists. For example, during the 1860s, Lucas records having visited the studios of 79 artists, sometimes repeatedly, and often either buying or commissioning works from the artist. Yet 52 of these artists are not mentioned in the diaries in connection with art dealers with whom Lucas did business. See The Diary of George A. Lucas: An American Art Agent in Paris, 1857-1909, Lillian M.C. Randall, ed. (Princeton: Princeton University Press, 1979). 42Paul Lacroix, Annuaire des Artistes et des Amateurs (Paris: Jules Renouard, 1861), p. 59. We count 105 galleries in Lacroix's listing, but the difference is unimportant. 
43Philippe Burty, "L'Hotel des Ventes et le Commerce des Tableaux," in Paris Guide par les Principaux Ecrivains et Artistes de la France (Paris: Librairie Internationle, 1867), vol. 2, pp. 949-63.

${ }^{44}$ Ibid., p. 963.

${ }^{45}$ Randall, "Introduction," The Diary of George A. Lucas, vol. 1, p. 17.

${ }^{46} \mathrm{~S}$. Monneret, L'Impressionnisme et son Epoque. Dictionnaire International (Paris:

Robert Laffont, 1987), vol. 2, pp. 313-14. Monneret, moreover, simply lists important dealers in contemporary painting; not all of the galleries she cites bought from the Impressionists.

${ }^{47}$ See Anne Distel, Impressionism: The First Collectors (New York: Abrams, 1990), pp. 33-34.

48See Emile Zola, "Ébauche," for L'Oeuvre, reprinted in Les Oeuvres Complètes, vol. 31

(Paris: Bernouard, 1928), pp. 409-17, in which he describes the various classes of dealers to be encountered in Paris in the 1880s.

${ }^{49}$ A. Boime, "Entrepreneurial Patronage in Nineteenth-Century France," in Enterprise and Entrepreneurs in Nineteenth- and Twentieth-Century France, Edward C. Carter II, Robert Forster \& Joseph N Moody, eds. (Baltimore: Johns Hopkins University Press, 1976), pp. 137-207. Boime, however, also accepts uncritically the Whites' discussion of the role of dealers in the Parisian art world.

${ }^{50}$ See Louise d'Argencourt, "Bouguereau and the Art Market in France," in William Bouguereau 1825-1905 (Montreal: Museum of Fine Arts, 1984), pp. 95-103, esp. p. 102. ${ }^{51}$ Ibid., p. 103.

${ }^{52}$ See Durand-Ruel's discussion of his and Brame's tactics during this period in "Mémoires," pp. 158-69.

${ }^{53}$ Ibid., p. 166.

${ }^{54}$ Bourdieu, The Field of Cultural Production, p. 251.

${ }^{55}$ See William Hauptmann, "Juries, Protests, and Counter-Exhibitions Before 1850," Art Bulletin (March 1985): pp. 95-109 and Richard Wrigley, The Origins of French Art Criticism (Oxford: Oxford University Press, 1995), esp. chapter 1, "The Salon in Context."

${ }^{56}$ Stranahan, A History of French Painting, p. 264 and the preface to the1857 Salon catalogue, Explication des ouvrages de peinture, sculpture, gravure, hithographie et architecture des artistes vivants (Paris: Charles de Mourgues Freres, 1857).

${ }^{57}$ See Jensen, Marketing Modernism, pp. 84-85, and Lorne Huston, "Le Salon et les expositions d'art: réflexions à partier de l'expérience de Louis Martinet (1861-1865)," Gazette des beaux-arts 116 (July-August 1990), pp. 45-50.

${ }^{58}$ For a careful review of the origins of the Salon des refusés see Albert Boime, "The Salon des Refusés and the Evolution of Modern Art," Art Quarterly 32 (Winter 1969): pp. 411-26.

${ }^{59}$ See Paul Mantz, "Exposition du Boulevard des Italiens," Gazette des Beaux-Arts, vol. 14 (April 1, 1863): pp. 381-84.

${ }^{60}$ Our view is supported by Lorne Huston, "Le Salon et les expositions d'art" and J.-P. Bouillon, "Sociétés d'artistes et institutions officielles dans la second moitié du XIXe siècle," Romantisme 54 (1986): pp. 89-113. 
${ }^{61}$ John Rewald (The History of Impressionism, p. 313) quotes a letter from Degas to Tissot on the eve of the first Impressionist exhibition, in which he complains of Manet's unwillingness to exhibit outside the Salon. Degas declared that "The realist movement no longer needs to fight with others. It is, it exists, it has to show itself separately. There has to be a realist Salon. Manet doesn't understand that. I definitely believe him to be much more vain than intelligent." And Camille Pissarro later remarked to his son Lucien, that "Manet, great painter that he was, had a petty side, he was crazy to be recognized by the constituted authorities, he believed in success, he longed for honors." See the letter dated December 28, 1883, in Letters to His Son Lucien, J. Rewald, ed. (New York: Pantheon Books, 1943).

${ }^{62}$ Castagnary, "Le Salon de 1873," reprinted in Castagnary, Salons, vol. 2, 1872-1879 (Paris, 1892), pp. 62-63, cited in translation by Rewald, The History of Impressionism, p. 306.

${ }^{63}$ Bourdieu agrees with Jacques Lethève that the refusés exhibition in 1863 represented a fatal blow to the Salon system because the Academy was once again stripped of its control over the Salon (it now passed primarily to the state) and would later lose its monopolies over art instruction. Yet it is obvious that for the next decade the Salon continued to dominate the French art world. Subsequent refusés exhibitions would have negligible impact, so that the Salon's hegemony, if not the Academy's, would remain unchallenged until the Impressionists. See Bourdieu, The Field of Cultural Production, p. 252.

${ }^{64}$ Mainardi, The End of the Salon, p. 165, note 29. ${ }^{65}$ See The New Painting: Impressionism 1874-1886: Documentation, vol. 1, Reviews, ed. Ruth Berson (San Francisco: Fine Arts Museums of San Francisco, 1996). By notices, we mean published announcements that the exhibition was taking place, often listing a number of the important artists by name. Review articles actually discuss individual artists and their work.

${ }^{66}$ See Rewald, History of Impressionism, p. 313 and p. 373. Incidentally, Durand-Ruel did nothing to support the exhibition in 1876, taking half the rent in cash up front and making up the other half in ticket receipts. Richard Brettell, "The 'First' Exhibition of Impressionist Painters," in The New Painting: Impressionism: 1874-1886, ed. Charles Moffett (San Francisco: The Fine Arts Museum of San Francisco, 1986), pp. 189-202, esp. p. 191, assumes that first Nadar and then Durand-Ruel would have handled "security, admissions, and sales." However there appears to be no actual record either supporting or refuting Brettell's assertion.

${ }^{67}$ In 1874 most critics did not regard Paul Cézanne as a core Impressionist. Nonetheless, he ranked near the top of the non-core group of painters in number of mentions. ${ }^{68}$ See Stranahan, A History of French Painting, pp. 266-69, for her discussion of Napoleon III's reforms.

${ }^{69}$ Even John Rewald (The History of Impressionism, p. 318) suggested that "From the beginning the exhibition seems to have been well attended, but the public went there mainly to laugh. Someone invented a joke to the effect that these painters' method consisted in loading a pistol with several tubes of paint and firing at a canvas, then finishing off the work with a signature. The critics were either extremely harsh in their comments or simply refused to consider the show seriously." Compare this with Paul 
Tucker's discussion of the mixed critical reception in "The First Impressionist Exhibition in Context," The New Painting, pp. 93-117, esp. 106-09.

${ }^{70}$ Gérôme's article, which appeared in the L'univers illustré (March 18, 1882), is reprinted in Berson, vol. 2, pp. 389-90. See esp. p. 390.

${ }^{71}$ See Rewald, The History of Impressionism, p. 500; pp. 503-15, and Rewald, PostImpressionism, 2nd ed. (New York: Museum of Modern Art, 1962), pp.32-36 for an overview of the events leading up to the first exhibition of the Group des Artistes Indépendants in May 1884, followed by the first exhibition of the Société des Artistes Indépendants in December 1884 (at which both Seurat and Paul Signac showed their paintings for the first time).

${ }^{72}$ Although initially the Indépendants exhibitions were not reviewed in anything like the numbers the Impressionist exhibitions received, they were still significant, both in number and in the importance of the critics who reviewed them. Based on the bibliography of contemporary criticism cited by John Rewald and Henri Dorra in Seurat (Paris: Les Beaux-arts, 1959) there were at least three reviews by Paris periodicals of the show of the Group des Artistes Indépendants. The winter exhibition in 1884, the first show of the refashioned Société des Artistes Indépendants, received at least five. The next exhibition on the Indépendants in 1886 received eight or more.

${ }^{73}$ Canvases and Careers, p. 99.

${ }^{74}$ The list of artists who debuted in artist-run exhibition societies before 1914 is far too long to cite here. But one has only to think of the importance of the Central European Secessions or of such small exhibition societies as the Futurists or Der Blaue Reiter to realize that with only one or two exceptions (most notably Picasso) all the important modern artists before World War I made their names through exhibiting with such organizations and not through dealer-sponsored shows.

${ }^{75}$ Canvases and Careers, p. 150.

${ }^{76}$ Ibid., p. 121.

${ }^{77}$ Ibid., p. 123.

${ }^{78}$ Vincent van Gogh, The Complete Letters of Vincent van Gogh (London: Thames and Hudson, 1958), vol. 3, pp. 251-52.

${ }^{79}$ See Émile Zola, "Mon Salon," (1868) reprinted in Mon Salon, Manet, écrits sur l'art (Paris, 1970), pp. 45-89; Théodore Duret, "Les peintres impressionnistes," (1878), reprinted in Critique d'avant-garde (Paris, 1885), pp. 64-69; Stéphane Mallarmé, "The Impressionists and Edouard Manet," (1876) reprinted in The New Painting, pp. 27-35; Edmond Duranty, "The New Painting," (1876) reprinted in The New Painting, pp. 37-49. ${ }^{80}$ Norma Broude, ed., Seurat in Perspective (Englewood Cliffs, N. J.: Prentice-Hall, 1978), p. 105.

${ }^{81}$ Ibid., p. 105.

${ }^{82}$ See Robert J. Niess, L'Oeuvre: Zola, Cézanne and Manet (Ann Arbor: University of Michigan Press, 1968).

${ }^{83}$ Canvases and Careers, p. 128.

${ }^{84}$ One exception is Linda Whiteley, "Accounting for Tastes," Oxford Art Journal, no. 2 (April 1979): pp. 25-28.

${ }^{85}$ For a discussion of Durand-Ruel's purchases of Manet, see Anthea Callen, "Faure and Manet," Gazette des beaux-arts (1974): pp. 157-78. For his acquisitions of the 
Impressionists during 1872-73 see Ralph E. Shikes and Paula Harper, Pissarro. His Life and Work (New York: Horizon, 1980),pp. 105ff. and Daniel Wildenstein, Monet or the Triumph of Impressionism, vol. 1 (Cologne: Taschen Verlag, 1996), pp. 92-100.

${ }^{86}$ Durand-Ruel continued to buy from Pissarro, but in markedly diminished numbers, which ended finally in 1875 . Renoir, whom Durand-Ruel had previously shown little interest in prior to 1875 , benefited from a spate of purchases by the dealer by the end of 1876. According to Anne Distel, Durand-Ruel acquired some fifteen canvases. Significantly, however, the only paintings that may be identified with certainty were "those that he sold to Count Armand Doria in July 1876, which reappeared on the market when Doria's collection was auctioned in 1899." See Distel, "Renoir's Collectors: the pâtissier, the priest and the prince," in Renoir (London: Arts Council of Great Britain, 1980), pp. 19-29, esp. p. 21.

${ }^{87}$ The scholarly literature on Degas provides little indication of the quantity of DurandRuel's purchases from the artist at any period in his career.

${ }^{88}$ It was at this time that Theo van Gogh was able to make substantial inroads in DurandRuel's business relationship with Monet. In 1888, for example, van Gogh purchased 23,450 francs worth of pictures from the artist, whereas Durand-Ruel appears to have bought very little. See Wildenstein's discussion of Monet's dealings with Durand-Ruel, Petit, and van Gogh in the 1880s in Monet or the Triumph of Impressionism, vol. 1, pp. $206 \mathrm{ff}$.

${ }^{89}$ On Durand-Ruel's declining purchases of Pissarro's pictures see Shikes and Harper, pp. $181 \mathrm{ff}$.

${ }^{90}$ Distell, Impressionism: The First Collectors, pp. 56ff.

${ }^{91}$ The "rescue" of Impressionism by the opening of the American market is an idea that first appeared in early twentieth-century literature on Durand-Ruel. See, for example, the essays by Arsène Alexandre, "Paul Durand-Ruel: Bild und Geschichte eines Kunsthändlers," Pan, vol. 2, no. 4 (November 1911), pp. 115-122, esp. p. 120 and Julius Elias, "Paul Durand-Ruel: Aus dem Leben eines modernen Kunsthäandler," Kunst und Künstler, vol. 10, no. 2 (November 1911): pp. 105-107, esp. p. 107.

${ }^{92} \mathrm{On}$ Cassatt and the first American collectors see Frances Weitzenhoffer, The Havemeyers: Impressionism Comes to America (New York: Abrams, 1986). ${ }^{93}$ D. Wildenstein, Monet, vol. 1, p. 206.

${ }^{94}$ Van Gogh's activities on behalf of Monet (and to a much smaller degree, the other Impressionists) is well documented in John Rewald's "Theo van Gogh, Goupil, and the Impressionists," Gazette des Beaux-Arts, v. 81 (January 1973): pp. 1-64 and (February 1973): pp. 65-108.

${ }^{95} Z$ ola, "Ebauche," p. 421, described Petit's gallery as a "palace" where "il monte des galeries, attend l'arrivage des Américains qui se produit en mai. . .Une bourse à tableaux, un syndicat pour faire monter les tableaux."

${ }^{96}$ Pissarro, Letters to His Son Lucien, p. 174, was still complaining in 1891 about the lack of competition between dealers: “At Boussod \& Valadon's they soft-soap me and talk against Durand. If I go to Durand's they become furious, and if I go to Boussod's, Durand is no more furious; in short: neither will buy my work. If anyone else were available, I would unhesitatingly turn to him, but there is nobody." 
${ }^{97}$ See Richard Thomson's discussion of the absence of dealer support for the advanced art of the 1880s in his catalogue essay "The Cultural Geography of the Petit Boulevard," in Vincent van Gogh and the Painters of the Petit Boulevard, ed. Cornelia Homburg (St. Louis: St. Louis Art Museum, 2001), esp. pp. 71-82

${ }^{98}$ For a discussion of Gauguin's shows at van Gogh's see John Rewald, Post-

Impressionism, p. 76, pp. 248-52.

${ }^{99}$ Canvases and Careers, p. 150.

${ }^{100}$ Ibid., p. 98.

${ }^{101}$ Ibid., p. 155; also p. 88.

102 Ibid., p. 155; also p. 88.

${ }^{103}$ Interestingly, Paul Gauguin made this point in 1902, when he described the

Impressionists' group exhibitions as “one of the most influential efforts ever made in France, only a handful of men, with only one weapon, their talent, successfully doing battle against a fearsome power made up of Officaldom, the Press, and Money;" The Writings of a Savage (New York: Da Capo Press, 1996), p. 225.

${ }^{104}$ Canvases and Careers, p. 158.

105 Ibid., p. 128.

106 Ibid., p. 151.

${ }^{107}$ Meyer Schapiro, Worldview in Painting - Art and Society (New York: George Braziller, 1999), p. 203.

${ }^{108}$ Galenson, Painting outside the Lines (Cambridge: Harvard University Press, 2001), Chap. 5.

${ }^{109}$ See Galenson, "Masterpieces and Markets: Why the Most Famous Modern Paintings are not by American Artists," Historical Methods, forthcoming. 
Table \# 1 Successful Salon Careers of Some Notable 19th Century French Painters Age of the artist when granted medal, title or chair

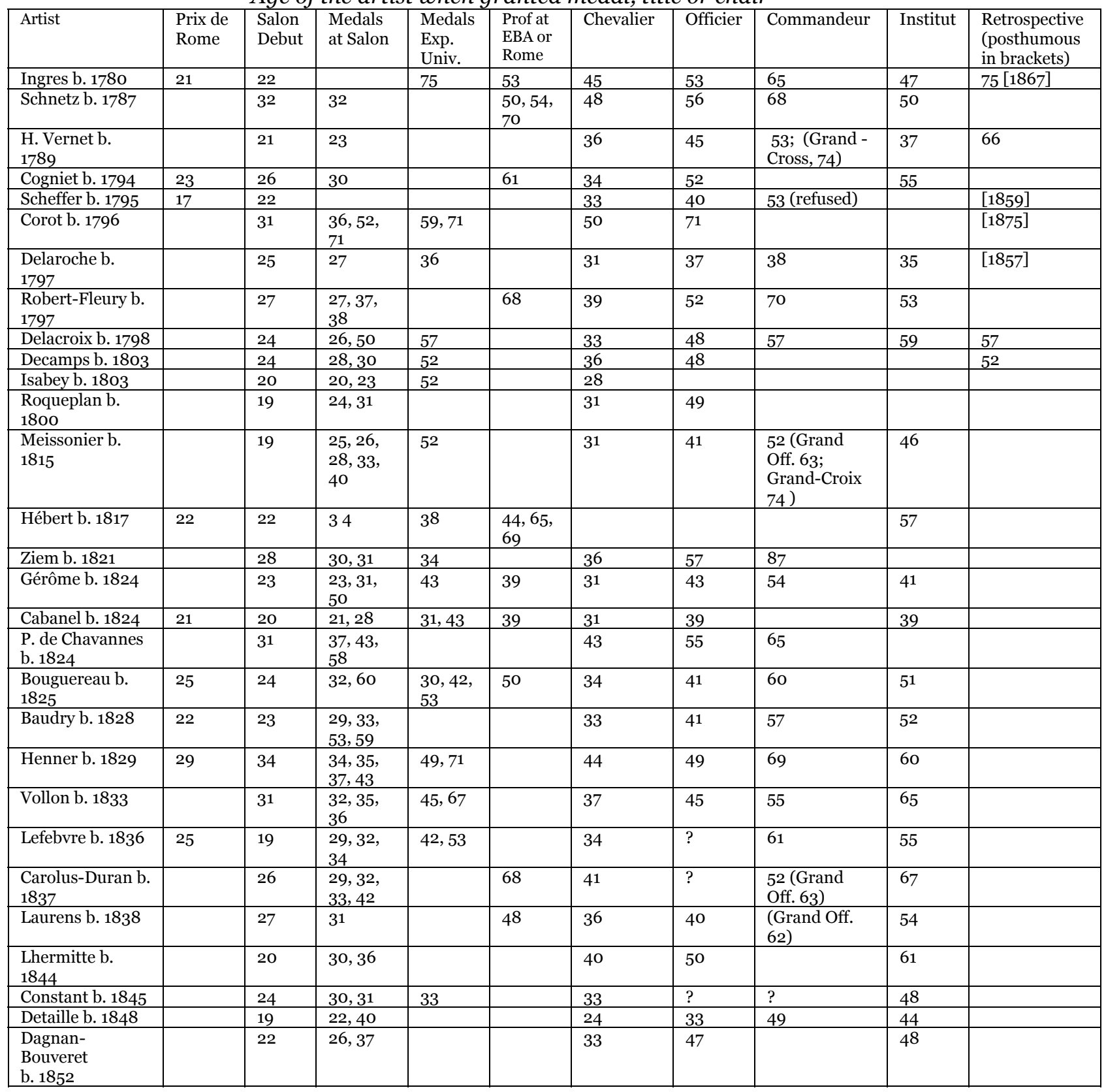

Sources: Clara Stranahan, A History of French Painting (New York: Putnam and Sons, 1893) with additional information taken from E. Bénézit, Dictionnaire critique et documentaire des peintres, sculpteurs. ... (Paris: Gründ, c. 1999) and Ulrich Thieme and Felix Becker, Allgemeines Lexikon der bildenden Künstler von der Antike bis zur Gegenwart (Leipzig: W. Engelmann, 1907-). 
Table \#2: Ranking of artists by number of reviews of first Impressionist exhibition that specifically discuss an artist's work.

\begin{tabular}{|l|l|l|l|}
\hline $\begin{array}{l}\text { No. of } \\
\text { reviews }\end{array}$ & Artist & $\begin{array}{l}\text { No. of } \\
\text { reviews }\end{array}$ & Artist \\
\hline 20 & Degas & 4 & Guillaumin \\
\hline 19 & Monet & 4 & Latouche \\
\hline 17 & Morisot & 3 & Cals \\
\hline 17 & Sisley & 3 & Mulot-Durivage \\
\hline 16 & Pissarro & 3 & A. Ottin \\
\hline 16 & Renoir & 3 & L. Ottin \\
\hline 11 & Lépine & 2 & Bureau \\
\hline 10 & Boudin & 2 & Levert \\
\hline 10 & Braquemond & 2 & Meyer \\
\hline 10 & Cézanne & 1 & Beliard \\
\hline 9 & Astruc & 1 & Debras \\
\hline 9 & Rouart & 0 & Attendu \\
\hline 8 & de Nittis & 0 & Lejeune \\
\hline 7 & Brandon & 0 & Robert \\
\hline
\end{tabular}

Source: Ruth Berson, ed., The New Painting: Impressionism 1874-1886: Documentation, vol. 1 (San Francisco: Fine Arts Museums of San Francisco, 1996), pp. 9-43.

The reviews were:

1. Ariste, "Salon de 1874," L'Indépendance belge (13 June 1874)

2. Ph. Burty, "The Paris Exhibition: Lex Impressionnistes," The Academy (30 May 1874)

3. E. C. "Chronique: Beaux-Arts: Expositions de peintures modernes," Revue de France (April 1874)

4. Emile Cardon, "Avant le Salon: L’Exposition des révoltés," La Presse (29 April 1874)

5. Etienne Carjat, "L’Exposition du boulevard des Capucines," La Patriote français (27 April 1874)

6. Castagnary, "Exposition du boulevard des Capucines: Les Impressionnistes," Le Siècle (29 April 1874)

7. Ernest Chesneau, "A côté du Salon: II. Le Plein Air: Exposition du boulevard des Capucines," Paris-

Journal (7 May 1874)

8. E. Drumont, "L’Exposition du boulevard des Capucines," Le Petit Journal (19 April 1874)

9. F. de Gantès, "Courrier artistique: L’Exposition du boulevard," La Semaine parisienne (23 April 1874)

10. E. d'H., "L’Exposition du boulevard des Capucines," Le Rappel (17 April 1874)

11. E. Lepelletier, "Chronique parisienne: L'Exposition libre du boulevard des Capucines," Le Patriote français (19 April 1874)

12. Louis Leroy, "L’Exposition des impressionnistes," Le Charivari (25 April 1874)

13. Léon de Lora, "Petites Nouvelles artistiques: Exposition libre des peintres," Le Gaulois (18 April 1874)

14. C. de Malte, "Exposition de la société anonyme des artistes peintres, sculpteurs, graveurs et

lithographes," Paris à l'eau-forte (19

April 1874)

15. Marc de Montifaud, "Exposition du boulevard des Capucines," L'Artiste (1 May 1874)

16. Henri Polday, "Les Intransigeants," La Renaissance littéraire et artistique (3 May 1874)

17. [Philippe Burty], "Chronique du jour," La Republique française (25 April 1874)

18. [Emile Zola], "Lettre de Paris," Le Sémaphore de Marseille (18 April 1874)

19. Armand Silvestre, "Chronique des beaux-arts: Physiologie du refusé - L'Exposition des révoltés,"

L'Opinion nationale (22 April 1874)

20. Pierre Véron, "Chronique parisienne," Le Journal amusant (25 April 1874) 
Table \#3: Durand-Ruel's Annual Purchases from Monet and Pissarro from 1871 to 1885

(in francs)

\begin{tabular}{|l|l|l|l|l|l|}
\hline Year & Monet & Pissarro & Year & Monet & Pissarro \\
\hline 1871 & 300 & 400 & 1879 & O & O \\
\hline 1872 & 9,800 & 5,900 & 1880 & 500 & O \\
\hline 1873 & 19,100 & 5,300 & 1881 & 20,900 & O \\
\hline 1874 & o & 2,535 & 1882 & $31,241^{*}$ & 12,000 \\
\hline 1875 & o & 1,190 & 1883 & $34,541^{*}$ & 14, o00 \\
\hline 1876 & o & O & 1884 & 18,200 & 10,000 \\
\hline 1877 & o & O & 1885 & 10,400 & 9,000 \\
\hline 1878 & O & O & & & \\
\hline
\end{tabular}

Sources: Daniel Wildenstein, Monet or the Triumph of Impressionism, vol. 1 (Cologne: Taschen Verlag, 1996); Ralph E. Shikes and Paula Harper, Pissarro: His Life and Work (New York:

Horizon Press, 1980) 